\title{
A COMPARATIVE STUDY OF EFFICACY OF DIPSI AND O'SULLIVAN'S METHOD OF SCREENING FOR GESTATIONAL DIABETES MELLITUS
}

\author{
Saranya Elancheran1, Sankareswari Raja ${ }^{2}$ \\ ${ }_{1}^{1}$ Assistant Professor, Department of Obstetrics and Gynaecology, Sri Venkateswaraa Medical College Hospital \& Research Center, \\ Ariyur, Pondicherry. \\ ${ }^{2}$ Associate Professor, Department of Obstetrics and Gynaecology, Sri Venkateswaraa Medical College Hospital \& Research Center, \\ Ariyur, Pondicherry.
}

ABSTRACT

\section{BACKGROUND}

The incidence of GDM is higher in India - 10-17.8\%. GDM has adverse outcomes of pregnancy and long term risk to mother and offspring which warrants an effective screening and diagnostic test for GDM. All complications of GDM are potentially preventable. This study compares the efficacy of DIPSI (Diabetes in Pregnancy Study Group India) with O'Sullivan's method in the screening of Gestational diabetes mellitus.

\section{MATERIALS AND METHODS}

This prospective study was conducted in antenatal clinic in outpatient department of Obstetrics and Gynaecology, Government Medical College during the period of August 2013 to July 2015. 500 pregnant women in each of study group between 24-28 weeks gestation were selected. DIPSI and O'Sullivan' tests were performed.

\section{RESULTS}

The incidence of GDM was $9 \%$ in O'Sullivan's group when compared to $12.5 \%$ in DIPSI group. The specificity of O'Sullivan's method in detecting GDM is only 95\% when compared to DIPSI. Highest incidence of GDM was observed in age group of 21-25 yrs. (64.44\% in O'Sullivan's group and $73.01 \%$ in DIPSI group), more in multigravida in both (88.88\% in O'Sullivan's group and $74.66 \%$ in DIPSI group), in Class V socioeconomic status in both (88.88\% in O'Sullivan's group and $83.33 \%$ in DIPSI group), with BMI $>25 \mathrm{~kg} / \mathrm{m}^{2} \mathrm{in}$ both $(73.33 \%$ in O'Sullivan's group and $83.3 \%$ in DIPSI group), incidence of polyhydramnios was 6\% in 0'Sullivan's group and $6.3 \%$ in DIPSI group. 83.33\% delivered at term in both the groups. Caesarean section was $61.1 \%$ in 0'Sullivan's group and 74\% in DIPSI group. The birth weight was in the range of $2.5-4 \mathrm{~kg}$ in both (77.77\% in 0'Sullivan's group and $68 \%$ in DIPSI group). 16.66\% $\%$ were treated with meal plan and $83.33 \%$ with insulin in O'Sullivan's group and $25 \%$ with meal plan and $75 \%$ with insulin in DIPSI group. Hypoglycaemia and hyperbilirubinaemia in babies is $12.5 \%$ in both the groups.

\section{CONCLUSION}

Screening with 50 g 0'Sullivan's method has only 95\% specificity compared to screening with 75 g DIPSI. DIPSI being a one-step procedure offers both as a screening and diagnostic test for GDM.

\section{KEYWORDS}

Gestational Diabetes Mellitus, O’Sullivan's Method, DIPSI Method.

HOW TO CITE THIS ARTICLE: Elancheran S, Raja S. A comparative study of efficacy of DIPSI and O'Sullivan's method of screening for gestational diabetes mellitus. J. Evolution Med. Dent. Sci. 2017;6(4):290-295, DOI: 10.14260/Jemds/2017/66

\section{BACKGROUND}

The most common endocrine disorder to complicate pregnancy is diabetes. Gestational diabetes mellitus is defined as carbohydrate intolerance with onset/recognition during pregnancy ${ }^{1}$. There is increase in incidence worldwide with a range of $0.4-10 \%$ (Dornhorst et al. 1998). ${ }^{2}$ The incidence of GDM is higher in India and ranges from 10$17.8 \%$. GDM has adverse outcomes of pregnancy including polyhydramnios, preeclampsia, macrosomia and shoulder dystocia. Longterm risk includes childhood obesity and type II DM in mother and offspring (Wilkins Huag L, et al(3)

Financial or Other, Competing Interest: None.

Submission 06-12-2016, Peer Review 30-12-2016,

Acceptance 05-01-2017, Published 12-01-2017.

Corresponding Author:

Dr. Sankareswari Raja,

Associate Professor,

Sri Venkateswara Medical College Hospital \& Research Center,

Ariyur, Pondicherry-605102.

E-mail:mlrsreekrishna@gmail.com

DOI: $10.14260 /$ jemds $/ 2017 / 66$
Metzger et al) which warrants an effective screening and diagnostic test for GDM. Ethnically Indian women are prone to develop glucose intolerance by eleven fold when compared to whites necessitating universal screening during pregnancy. Hence, an appropriate screening test for GDM has been much emphasised. All complications of GDM are potentially preventable with early recognition and intense monitoring. Over years there have been many controversies regarding best screening and diagnostic test for GDM. The testing for GDM by appropriate method at the earliest detects women who need treatment with either diet alone or a combination of diet with insulin therapy. This helps in prevention of maternal morbidity and mortality. This study compares the efficacy of DIPSI (Diabetes in Pregnancy Study Group India) with O'Sullivan's method in the screening of Gestational diabetes mellitus in general population.

\section{MATERIALS AND METHODS}

This prospective study was conducted in antenatal clinic in outpatient department of Obstetrics and Gynaecology, Government Theni Medical College during the period of August 2013 to July 2015. 500 pregnant women randomly 
allotted in each of study group between 24-28 weeks gestation who attend antenatal clinic of GTMCH, Theni. Inclusion criteria were women aged between 17-40 yrs., women with singleton gestation, women with no past history of GDM or DM, not on any treatment for other medical illness. Exclusion criteria were known case of type $1 \& 2$ diabetes mellitus, women with multiple gestations, autoimmune disorders like systemic lupus erythematosus, thyroid disorder, PCOS. 500 Pregnant women in each group between 24-28 weeks of gestation are selected for study.

\section{Method of Performing 0'Sullivan's Test}

Patient is asked to drink $50 \mathrm{~g}$ of glucose dissolved in $200 \mathrm{~mL}$ of water, without regard to time or day of last meal. Those with blood glucose level $>/=140 \mathrm{mg} / \mathrm{dL}$ after 1 hour are considered to be positive.

Method of Performing $100 \mathrm{~g}$ OGTT (ADA Criteria): Those who are positive at screening test using a cut-off of $>/=140$ $\mathrm{mg} / \mathrm{dL}$ will undergo confirmatory oral glucose tolerance test with $100 \mathrm{~g}$ of oral glucose. Patient will be instructed to come after 72 hours after overnight fasting (8-14 hours). She should take a carbohydrate unrestricted diet (not less than 150 grams per day) for 3 days before test is performed. Fasting venous sample is obtained. 100 grams of glucose is dissolved in $200-400 \mathrm{~mL}$ of water and is asked to drink in 5 minutes. Venous blood is drawn after 1, 2 and 3 hours.

ADA CRITERIA -100 g OGTT by Carpenter and Coustan method
Time - Plasma glucose values
Fasting - $\quad>/=95 \mathrm{mg} / \mathrm{dL}$
$1 \mathrm{hr} \quad-\quad>/=180 \mathrm{mg} / \mathrm{dL}$
$2 \mathrm{hr} \quad-\quad>/=155 \mathrm{mg} / \mathrm{dL}$

When two or more values meet or exceed this value GDM is diagnosed.

Method of Performing DIPSI (Diabetes in Pregnancy Study Group India):

Glucose value (venous sample) is measured $2 \mathrm{hrs}$. after 75 $\mathrm{g}$ of oral glucose irrespective of last meal. GDM is diagnosed if plasma glucose level exceeds $140 \mathrm{mg} / \mathrm{dL}$.

\section{RESULTS}

\begin{tabular}{|c|c|}
\hline $\begin{array}{c}\text { Total Number of Cases Screened Using O'Sullivan } \\
\text { method }\end{array}$ & 500 \\
\hline Total Number of Cases Screened Using DIPSI & 500 \\
\hline $\begin{array}{c}\text { Number of cases detected having GDM (Using } \\
\text { O'Sullivan method) }\end{array}$ & 45 \\
\hline Number of cases detected having GDM (Using DIPSI) & 63 \\
\hline Incidence of GDM (Using O'Sullivan method) & $9 \%$ \\
\hline Incidence of GDM (Using DIPSI) & $12.5 \%$ \\
\hline Table 1. Incidence of Study \\
\hline
\end{tabular}

The incidence of Gestational diabetes mellitus in this study is $11 \%$.

\begin{tabular}{|c|c|c|c|c|c|c|c|}
\hline \multicolumn{2}{|c|}{ Age in Years } & \multirow{2}{*}{$\begin{array}{c}\text { No. with GDM } \\
\text { (O'Sullivan) }\end{array}$} & \multirow{2}{*}{$\begin{array}{c}\text { No. without GDM } \\
\text { (0' Sullivan) } \\
97\end{array}$} & \multirow{2}{*}{$\begin{array}{c}\text { Total } \\
97\end{array}$} & \multirow{2}{*}{$\begin{array}{c}\text { No. with GDM } \\
\text { (DIPSI) }\end{array}$} & \multirow{2}{*}{$\begin{array}{c}\text { No. without GDM } \\
\text { (DIPSI) }\end{array}$} & \multirow{2}{*}{$\begin{array}{c}\text { Total } \\
86\end{array}$} \\
\hline $17-20$ & No. of Pts. & & & & & & \\
\hline $17-20$ & Percentage & $0 \%$ & $21.468 \%$ & & $0 \%$ & $19.68 \%$ & \\
\hline \multirow{2}{*}{$21-25$} & No. of Pts. & 29 & 256 & 285 & 46 & 237 & 283 \\
\hline & Percentage & $64.4 \%$ & $57.07 \%$ & & $73.1 \%$ & $54.25 \%$ & \\
\hline \multirow{2}{*}{$26-30$} & No. of Pts. & 14 & 90 & 104 & 15 & 101 & 116 \\
\hline & Percentage & $33.3 \%$ & $19.89 \%$ & & $23.8 \%$ & $23.4 \%$ & \\
\hline \multirow{2}{*}{$31-35$} & No. of Pts. & 2 & 10 & 12 & 2 & 11 & 13 \\
\hline & Percentage & $4 \%$ & $0.5 \%$ & & $3.0 \%$ & $2.65 \%$ & \\
\hline \multirow{2}{*}{$36-40$} & No. of Pts. & 0 & 2 & 2 & 0 & 2 & 2 \\
\hline & Percentage & $0 \%$ & $0.1 \%$ & & $0 \%$ & $0.46 \%$ & \\
\hline Total & & 45 & 455 & 500 & 63 & 437 & 500 \\
\hline
\end{tabular}

The Value of Chi-square statistics was found to be 13.6609 with a P-value of 0.00846 which is much significant at $\mathrm{p}<0.05$ for O’Sullivan method.

The Value of Chi-square statistics was found to be 16.22 with a P-value of 0.002736 which is much significant at $p<0.05$ for DIPSI method.

\begin{tabular}{|c|c|c|c|c|c|c|c|}
\hline \multicolumn{2}{|c|}{ Gravida Status } & \multirow{2}{*}{$\begin{array}{c}\begin{array}{c}\text { No. with GDM } \\
\text { (O' Sullivan) }\end{array} \\
5 \\
\end{array}$} & \multirow{2}{*}{$\begin{array}{c}\begin{array}{c}\text { No .without } \\
\text { GDM } \\
\text { (0' Sullivan) }\end{array} \\
217 \\
\end{array}$} & \multirow{3}{*}{$\begin{array}{c}\text { Total } \\
222\end{array}$} & \multirow{3}{*}{$\begin{array}{c}\begin{array}{c}\text { No. with GDM } \\
\text { (DIPSI) }\end{array} \\
15 \\
24 \% \\
\end{array}$} & \multirow{3}{*}{$\begin{array}{c}\begin{array}{c}\text { No. without GDM } \\
\text { (DIPSI) }\end{array} \\
172 \\
39.36 \% \\
\end{array}$} & \multirow{3}{*}{$\begin{array}{r}\text { Total } \\
187\end{array}$} \\
\hline \multirow{2}{*}{ Primi } & No. of Pts. & & & & & & \\
\hline & Percentage & $11.11 \%$ & $47.69 \%$ & & & & \\
\hline \multirow{2}{*}{ G2 } & No. of Pts. & 30 & 157 & \multirow{2}{*}{781} & 42 & 198 & \multirow{2}{*}{240} \\
\hline & Percentage & $66.66 \%$ & $34.55 \%$ & & $66.66 \%$ & $45.3 \%$ & \\
\hline \multirow{2}{*}{ G3 } & No. of Pts. & 10 & 55 & \multirow{2}{*}{65} & 5 & 55 & \multirow{2}{*}{60} \\
\hline & Percentage & $22.22 \%$ & $12.08 \%$ & & $8 \%$ & $12.7 \%$ & \\
\hline \multirow{2}{*}{ G4 and above } & No. of Pts. & 0 & 26 & \multirow{2}{*}{26} & 0 & 13 & \multirow{2}{*}{13} \\
\hline & Percentage & & $6 \%$ & & & $3 \%$ & \\
\hline Total & & 45 & 455 & 500 & 63 & 437 & 500 \\
\hline \multicolumn{8}{|c|}{ Table 3. Gravida study for GDM } \\
\hline
\end{tabular}

The value of Chi-square statistics is found to be 29.473 . With a P-Value of 0.00001 which is much significant at $p<0.001$ O'Sullivan.

The value of Chi-square statistics is found to be 11.801 . With a P-Value of 0.008097 which is much significant at p $<0.05-$ DIPSI. 


\begin{tabular}{|c|c|c|c|c|c|c|c|}
\hline \multicolumn{2}{|c|}{ Socio Economic Status } & \multirow{2}{*}{$\begin{array}{c}\begin{array}{c}\text { No. with GDM } \\
\text { (0' Sullivan) }\end{array} \\
0\end{array}$} & \multirow{2}{*}{$\begin{array}{c}\begin{array}{c}\text { No. without GDM } \\
\text { (O' Sullivan) }\end{array} \\
95 \\
\end{array}$} & \multirow{2}{*}{$\begin{array}{c}\text { Total } \\
95 \\
\end{array}$} & \multirow{2}{*}{$\begin{array}{c}\begin{array}{c}\text { No. with } \\
\text { GDM } \\
\text { (DIPSI) }\end{array} \\
0 \\
\end{array}$} & \multirow{2}{*}{$\begin{array}{c}\begin{array}{c}\text { No. without GDM } \\
\text { (DIPSI) }\end{array} \\
74 \\
\end{array}$} & \multirow{2}{*}{$\begin{array}{c}\text { Total } \\
74\end{array}$} \\
\hline Class III & No. of Pts. & & & & & & \\
\hline & Percentage & & $20.94 \%$ & & 0 & 17 & \\
\hline \multirow[t]{2}{*}{ Class IV } & No. of Pts. & 5 & 139 & 144 & 10 & 163 & 173 \\
\hline & Percentage & $11.11 \%$ & $31.93 \%$ & & 16.66 & 37.23 & \\
\hline \multirow{2}{*}{ Class V } & No. of Pts. & 40 & 221 & \multirow{2}{*}{261} & 53 & 200 & \multirow{2}{*}{253} \\
\hline & Percentage & $88.88 \%$ & $47.12 \%$ & & 83.33 & 45.74 & \\
\hline Total & & 45 & 455 & 500 & 63 & 437 & 500 \\
\hline
\end{tabular}

The value of Chi-square statistics is found to be 27.5199. With a P-Value of 0.00001 which is much significant at $p<0.001-0$ ' Sullivan.

The value of Chi-square statistics is found to be 33.98. With a P-Value of 0.00001 which is much significant at p<0.001- DIPSI.

\begin{tabular}{|c|c|c|c|c|c|c|c|}
\hline \multicolumn{2}{|c|}{ BMI (in $\mathbf{k g} / \mathrm{m}^{2}$ ) } & \multirow{2}{*}{$\begin{array}{c}\begin{array}{c}\text { No. with GDM } \\
\text { (0' Sullivan) }\end{array} \\
0\end{array}$} & \multirow{2}{*}{$\begin{array}{c}\begin{array}{c}\text { No. without GDM } \\
\text { (O' Sullivan) }\end{array} \\
35\end{array}$} & \multirow{3}{*}{$\begin{array}{c}\text { Total } \\
35\end{array}$} & \multirow{3}{*}{$\begin{array}{c}\begin{array}{c}\text { No. with } \\
\text { GDM } \\
\text { (DIPSI) }\end{array} \\
0\end{array}$} & \multirow{3}{*}{$\begin{array}{c}\begin{array}{c}\text { No. without GDM } \\
\text { (DIPSI) }\end{array} \\
58 \\
13.29\end{array}$} & \multirow{3}{*}{$\begin{array}{r}\text { Total } \\
58\end{array}$} \\
\hline \multirow{2}{*}{ Less than 18.5} & No. of Pts. & & & & & & \\
\hline & Percentage & & $7.85 \%$ & & & & \\
\hline \multirow[t]{2}{*}{$18.5-24.9$} & No. of Pts. & 3 & 272 & 275 & 5 & 285 & 290 \\
\hline & Percentage & $6 \%$ & $59.68 \%$ & & $8 \%$ & $65.43 \%$ & \\
\hline \multirow[t]{2}{*}{$25-29.9$} & No. of Pts. & 33 & 123 & 156 & 52 & 69 & 121 \\
\hline & Percentage & $73.33 \%$ & $27.22 \%$ & & $83.3 \%$ & $15.95 \%$ & \\
\hline \multirow{2}{*}{30 and above } & No. of Pts. & 9 & 25 & \multirow{2}{*}{34} & 6 & 26 & \multirow{2}{*}{32} \\
\hline & Percentage & $20 \%$ & $5.23 \%$ & & $8 \%$ & $5.3 \%$ & \\
\hline Total & & 45 & 455 & 500 & 63 & 437 & 500 \\
\hline \multicolumn{8}{|c|}{ Table 5. GDM Study of BMI } \\
\hline
\end{tabular}

The value of Chi-square statistics is found to be 65.272. With a P-Value of 0.00001 which is much significant at $\mathrm{p}<0.001$ (O'Sullivan).

The value of Chi-square statistics is found to be 143.17 . With a P-Value of 0.00001 which is much significant at $p<0.001$. (DIPSI).

\begin{tabular}{|c|c|c|c|c|c|c|c|}
\hline \multicolumn{2}{|c|}{ Family History } & $\begin{array}{l}\text { No. with GDM } \\
\text { (O' Sullivan) }\end{array}$ & $\begin{array}{l}\text { No. without GDM } \\
\text { (O' Sullivan) }\end{array}$ & Total & $\begin{array}{l}\text { with GDM } \\
\text { (DIPSI) }\end{array}$ & $\begin{array}{l}\text { without GDM } \\
\text { (DIPSI) }\end{array}$ & Total \\
\hline \multirow{2}{*}{ No Family history } & No. of Pts. & 21 & 376 & 397 & 33 & 349 & 382 \\
\hline & Percentage & $44.44 \%$ & $82.72 \%$ & & $50 \%$ & $79.58 \%$ & \\
\hline \multirow{2}{*}{ Father Diabetic } & No. of Pts. & 14 & 50 & 64 & 20 & 53 & 73 \\
\hline & Percentage & $33.33 \%$ & $9.4 \%$ & & $33.33 \%$ & $10.47 \%$ & \\
\hline \multirow{2}{*}{ Mother Diabetic } & No. of Pts. & 10 & 22 & 32 & 10 & 27 & 37 \\
\hline & Percentage & $22.22 \%$ & $5.75 \%$ & & $16.66 \%$ & $6.28 \%$ & \\
\hline \multirow{2}{*}{$\begin{array}{c}\text { No. of Pts. with family } \\
\text { H/O DM }\end{array}$} & No. of Pts. & 0 & 9 & 9 & 0 & 8 & 8 \\
\hline & Percentage & & $2.094 \%$ & & & $2 \%$ & \\
\hline Total & & 45 & 455 & $\mathbf{5 0 0}$ & 63 & 437 & 500 \\
\hline \multicolumn{8}{|c|}{ Table 6. Study of Family History of Diabetics } \\
\hline
\end{tabular}

The value of Chi-square statistics is found to be 43.2984. With a P-Value of 0.00001 which is much significant at $p<0.001$. $\left(0^{\prime}\right.$ Sullivan).

The value of Chi-square statistics is found to be 28.10 . With a P-Value of 0.00001 which is much significant at $\mathrm{p}<0.001$. (DIPSI).

\begin{tabular}{|c|c|c|c|c|c|c|c|}
\hline \multicolumn{2}{|c|}{ Risk Factors } & \multirow{2}{*}{$\begin{array}{c}\begin{array}{c}\text { No. with GDM } \\
\text { (0' Sullivan) }\end{array} \\
5\end{array}$} & \multirow{2}{*}{\begin{tabular}{|c|}
$\begin{array}{c}\text { No. without GDM (0' } \\
\text { Sullivan) }\end{array}$ \\
14 \\
\end{tabular}} & \multirow{2}{*}{$\begin{array}{c}\text { Total } \\
19\end{array}$} & \multirow{2}{*}{\begin{tabular}{|c|}
$\begin{array}{c}\text { Number with GDM } \\
\text { (DIPSI) }\end{array}$ \\
5 \\
\end{tabular}} & \multirow{2}{*}{$\begin{array}{c}\begin{array}{c}\text { Number without } \\
\text { GDM (DIPSI) }\end{array} \\
16 \\
\end{array}$} & \multirow{2}{*}{$\begin{array}{c}\text { Total } \\
21\end{array}$} \\
\hline History of & No. of Pts. & & & & & & \\
\hline Spontaneous Abortion & Percentage & $11.11 \%$ & \begin{tabular}{|c|}
$3.14 \%$ \\
\end{tabular} & & $8.33 \%$ & $3.72 \%$ & \\
\hline \multirow{2}{*}{ History of Sudden IUD } & No. of Pts. & 0 & 0 & 0 & 0 & 0 & 0 \\
\hline & Percentage & $0 \%$ & $0 \%$ & & & & \\
\hline \multirow{2}{*}{$\begin{array}{l}\text { History of Preterm } \\
\text { Delivery }\end{array}$} & No. of Pts. & 0 & 9 & 9 & 5 & 14 & 19 \\
\hline & Percentage & & $2.08 \%$ & & $8.33 \%$ & $3.191 \%$ & \\
\hline \multirow{2}{*}{$\begin{array}{l}\text { History of previous } \\
\text { GDM with IGT }\end{array}$} & No. of Pts. & 0 & 0 & 0 & 0 & 0 & 0 \\
\hline & Percentage & $0 \%$ & $0 \%$ & & & & \\
\hline \multirow{2}{*}{$\begin{array}{c}\text { History of previous } \\
\text { Pre-eclampsia }\end{array}$} & No. of Pts. & 14 & 18 & 32 & 15 & 13 & 28 \\
\hline & Percentage & $33.33 \%$ & $4.18 \%$ & & $25 \%$ & $3.12 \%$ & \\
\hline \multirow{2}{*}{\begin{tabular}{|c|} 
History of previous \\
babies with congenital \\
anomalies \\
\end{tabular}} & No. of Pts. & 0 & 0 & 0 & 0 & 0 & 0 \\
\hline & Percentage & $0 \%$ & $0 \%$ & & & & \\
\hline
\end{tabular}




\begin{tabular}{|c|c|c|c|c|c|c|c|}
\hline \multicolumn{2}{|c|}{ Risk Factors } & $\begin{array}{l}\text { No. with GDM } \\
\text { (0' Sullivan) }\end{array}$ & $\begin{array}{l}\text { No. without GDM } \\
\text { (O' Sullivan) }\end{array}$ & Total & $\begin{array}{l}\text { No. with GDM } \\
\text { (DIPSI) }\end{array}$ & $\begin{array}{l}\text { No. without GDM } \\
\text { (DIPSI) }\end{array}$ & Total \\
\hline \multirow{2}{*}{ Obesity } & No. of Pts. & 10 & 12 & 22 & 15 & 13 & 28 \\
\hline & Percentage & $22.2 \%$ & $2.6 \%$ & & $25 \%$ & $3.19 \%$ & \\
\hline \multirow{2}{*}{ Pre-eclampsia } & No. of Pts. & 1 & 6 & 7 & 3 & 14 & 17 \\
\hline & Percentage & $2 \%$ & $1.45 \%$ & & $4.7 \%$ & $3.19 \%$ & \\
\hline \multirow{2}{*}{ Hydramnios } & No. of Pts. & 3 & 5 & 8 & 4 & 8 & 12 \\
\hline & Percentage & $6 \%$ & $1 \%$ & & $6.3 \%$ & $1.59 \%$ & \\
\hline \multirow{2}{*}{$\begin{array}{c}\text { Congenital } \\
\text { Malformations }\end{array}$} & No. of Pts. & 0 & 0 & 0 & 0 & 0 & 0 \\
\hline & Percentage & $0 \%$ & $0 \%$ & & $0 \%$ & $0 \%$ & \\
\hline
\end{tabular}

\begin{tabular}{|c|c|c|c|c|}
\hline \multicolumn{2}{|c|}{ O' Sullivan in 1-hour 50 g } & \multicolumn{2}{c|}{ in 2-hour 75 g DIPSI } \\
\hline Blood Glucose Level & Number & Percentage & Number & Percentage \\
\hline $61-70$ & 10 & $2 \%$ & 2 & $5 \%$ \\
\hline $71-80$ & 32 & $6.5 \%$ & 25 & $22 \%$ \\
\hline $81-90$ & 107 & $21.5 \%$ & 110 & $28 \%$ \\
\hline $91-100$ & 150 & $30 \%$ & 140 & $21 \%$ \\
\hline $101-110$ & 95 & $19 \%$ & 40 & $8 \%$ \\
\hline $111-120$ & 50 & $10 \%$ & 15 & $3 \%$ \\
\hline $121-130$ & 5 & $1 \%$ & 5 & $1 \%$ \\
\hline $131-140$ & 10 & $2 \%$ & 18 & $5.4 \%$ \\
\hline $141-150$ & 15 & $3 \%$ & 13 & $3.6 \%$ \\
\hline $151-160$ & 11 & $2 \%$ & 5 & $2.6 \%$ \\
\hline 171 \& Above & 14 & $2.8 \%$ & $1 \%$ \\
\hline
\end{tabular}

\begin{tabular}{|c|c|c|c|c|c|c|c|}
\hline \multicolumn{2}{|c|}{ Gestational Age } & \multirow{2}{*}{$\begin{array}{c}\begin{array}{c}\text { No. with GDM (0' } \\
\text { Sullivan) }\end{array} \\
37 \\
\end{array}$} & \multirow{2}{*}{$\begin{array}{c}\begin{array}{c}\text { No. without GDM (0' } \\
\text { Sullivan) }\end{array} \\
410\end{array}$} & \multirow{2}{*}{$\begin{array}{c}\text { Total } \\
447\end{array}$} & \multirow{2}{*}{$\begin{array}{c}\begin{array}{c}\text { No. with GDM } \\
\text { (DIPSI) }\end{array} \\
53 \\
\end{array}$} & \multirow{2}{*}{$\begin{array}{c}\begin{array}{c}\text { No. without GDM } \\
\text { (DIPSI) }\end{array} \\
376\end{array}$} & \multirow{2}{*}{$\begin{array}{c}\text { Total } \\
429\end{array}$} \\
\hline Torm & No. of Pts. & & & & & & \\
\hline lerm & Percentage & $83.33 \%$ & $90.20 \%$ & & $83.33 \%$ & $86.17 \%$ & \\
\hline \multirow{2}{*}{ Preterm } & No. of Pts. & 8 & 25 & 33 & 10 & 27 & 37 \\
\hline & Percentage & $16.66 \%$ & $5.6 \%$ & & $16.66 \%$ & $6.3 \%$ & \\
\hline \multirow{2}{*}{ Post Dated } & No. of Pts. & 0 & 19 & 19 & 0 & 23 & 23 \\
\hline & Percentage & $0 \%$ & $4.12 \%$ & & $0 \%$ & $5.3 \%$ & \\
\hline Total & & 45 & 455 & 500 & 63 & 437 & 500 \\
\hline \multicolumn{8}{|c|}{ Table 10. Gestational Age at Delivery } \\
\hline
\end{tabular}

\begin{tabular}{|c|c|c|c|c|c|c|c|}
\hline \multicolumn{2}{|c|}{ Mode of Delivery } & $\begin{array}{l}\text { No. with GDM (O' } \\
\text { Sullivan) }\end{array}$ & \begin{tabular}{|c|}
$\begin{array}{c}\text { No. without GDM (0' } \\
\text { Sullivan) }\end{array}$ \\
\end{tabular} & Total & $\begin{array}{l}\text { No. With GDM } \\
\text { (DIPSI) }\end{array}$ & \begin{tabular}{|c|} 
No. Without GDM \\
(DIPSI)
\end{tabular} & Total \\
\hline \multirow{2}{*}{ Labour naturale } & No. of Pts. & & 61 & 61 & 0 & 35 & 35 \\
\hline & Percentage & & $13.54 \%$ & & & $8 \%$ & \\
\hline \multirow{2}{*}{$\begin{array}{l}\text { Labour naturale with } \\
\text { episiotomy }\end{array}$} & No. of Pts. & 17 & 251 & 268 & 15 & 276 & 291 \\
\hline & Percentage & $38.88 \%$ & $55.2 \%$ & & $24 \%$ & $63.3 \%$ & \\
\hline \multirow{2}{*}{ Outlet forceps } & No. of Pts. & & 19 & 19 & & 13 & 13 \\
\hline & Percentage & & $4.1 \%$ & & & $3 \%$ & \\
\hline \multirow{2}{*}{ Assisted breech } & No. of Pts. & & 5 & 5 & & 2 & 2 \\
\hline & Percentage & & $1.04 \%$ & & & $0.5 \%$ & \\
\hline \multirow{2}{*}{ Emergency section } & No. of Pts. & 13 & 76 & 89 & 20 & 63 & 83 \\
\hline & Percentage & $27.77 \%$ & $16.66 \%$ & & $31 \%$ & $14.36 \%$ & \\
\hline \multirow{2}{*}{ Elective section } & No. of Pts. & 15 & 43 & 58 & 28 & 46 & 74 \\
\hline & Percentage & $33.33 \%$ & $9.37 \%$ & & $43 \%$ & $10.6 \%$ & \\
\hline Total & & 45 & 455 & 500 & 63 & 437 & 500 \\
\hline
\end{tabular}

\begin{tabular}{|c|c|c|c|c|c|c|c|}
\hline \multicolumn{2}{|c|}{ Range of Weight } & $\begin{array}{l}\text { No. with GDM (O' } \\
\text { Sullivan) }\end{array}$ & $\begin{array}{c}\text { No. without GDM (O' } \\
\text { Sullivan) }\end{array}$ & Total & $\begin{array}{l}\text { N with GDM } \\
\text { (DIPSI) }\end{array}$ & $\begin{array}{l}\mathrm{N} \text { without GDM } \\
\text { (DIPSI) }\end{array}$ & Total \\
\hline \multirow{2}{*}{$<2.5 \mathrm{Kg}$} & No. of Pts. & 8 & 36 & 44 & 16 & 26 & 42 \\
\hline & Percentage & $16.66 \%$ & $8 \%$ & & $25 \%$ & $6 \%$ & \\
\hline \multirow{2}{*}{2.5 To $4 \mathrm{Kg}$} & No. of Pts. & 35 & 412 & 447 & 43 & 405 & 449 \\
\hline & Percentage & $77.77 \%$ & $90.20 \%$ & & $68 \%$ & $93 \%$ & \\
\hline \multirow{2}{*}{$>4 \mathrm{Kg}$} & No. of Pts. & 2 & 5 & 9 & 4 & 5 & 9 \\
\hline & Percentage & $4 \%$ & $1 \%$ & & $6 \%$ & $1.1 \%$ & \\
\hline Total & & 45 & 455 & 500 & 63 & 437 & 500 \\
\hline
\end{tabular}




\begin{tabular}{|c|c|c|c|c|c|c|c|}
\hline \multicolumn{2}{|c|}{ Management } & $\begin{array}{l}\text { No. with GDM } \\
\text { (O' Sullivan) }\end{array}$ & $\begin{array}{l}\text { No. without GDM } \\
\text { (O' Sullivan) }\end{array}$ & Total & $\begin{array}{l}\text { No. with GDM } \\
\text { (DIPSI) }\end{array}$ & $\begin{array}{l}\text { No. without GDM } \\
\text { (DIPSI) }\end{array}$ & Total \\
\hline \multirow{2}{*}{ No Treatment } & No. of Pts. & 0 & 455 & 455 & 0 & 437 & 188 \\
\hline & Percentage & & $100 \%$ & & & $100 \%$ & \\
\hline \multirow{2}{*}{ Meal Plan } & No. of Pts. & 8 & 0 & 8 & 16 & 0 & 16 \\
\hline & Percentage & $16.66 \%$ & $0 \%$ & & $25 \%$ & $0 \%$ & \\
\hline \multirow{2}{*}{ Insulin } & No. of Pts. & 37 & 0 & 37 & 47 & 0 & 47 \\
\hline & Percentage & $83.33 \%$ & $0 \%$ & & $75 \%$ & 0 & \\
\hline Total & & 45 & 455 & 500 & 63 & 437 & 500 \\
\hline \multicolumn{8}{|c|}{ Table 13. Management plan of GDM } \\
\hline
\end{tabular}

\begin{tabular}{|c|c|c|c|c|c|c|c|}
\hline \multicolumn{2}{|c|}{ Admission Status } & $\begin{array}{c}\text { No. with } \\
\text { GDM (O'Sullivan) }\end{array}$ & $\begin{array}{l}\text { No. without GDM } \\
\text { (0' Sullivan) }\end{array}$ & Total & $\begin{array}{l}\text { No. with GDM } \\
\text { (DIPSI) }\end{array}$ & $\begin{array}{l}\text { No. without GDM } \\
\text { (DIPSI) }\end{array}$ & Total \\
\hline \multirow{2}{*}{ Not Admitted } & No. of Pts. & 30 & 396 & 426 & 52 & 350 & 402 \\
\hline & Percentage & $66.66 \%$ & $87.11 \%$ & & $83.33 \%$ & $80 \%$ & \\
\hline \multirow{2}{*}{ Admitted } & No. of Pts. & 15 & 59 & 74 & 11 & 87 & 98 \\
\hline & Percentage & $33.33 \%$ & $12.88 \%$ & & $16.66 \%$ & $20 \%$ & \\
\hline Total & & 45 & 455 & 500 & 45 & 455 & 500 \\
\hline
\end{tabular}

\section{DISCUSSION}

In this study group, that involves 1000 pregnant women, 500 were randomly allocated to undergo either O'Sullivan or DIPSI. The incidence of Gestational diabetes mellitus in this study was $11 \%$, out of which DIPSI detected $12.5 \%$ and O'Sullivan detected $9 \%$ of cases. (Table 1,9). The incidence of GDM is higher in India and ranges from $10-17.8 \%$. A national survey conducted recently reported the prevalence of Impaired Glucose Tolerance (IGT) in age group between 2029 yrs. as $12.2 \%$ and between $30-39$ yrs. as $15.3 \%$ respectively (Seshiah et al).(4) The prevalence of GDM in urban, semi-urban and rural areas are 17.8\%, 13.8\% and $9.9 \%$ respectively in a community based survey by Seshiah et al, 2008.(5) Study conducted by Prathiba et al,(6) 17\% had abnormal glucose challenge test in O'Sullivan's group and $24 \%$ had abnormal glucose tolerance in DIPSI group which is higher than this study. The prevalence of GDM in India varies from $3.8 \%$ to $21 \%$ depending on geographical location.

\section{Prevalence of GDM}

\begin{tabular}{|c|c|c|}
\hline Author & Location & Prevalence \\
Magee & Seattle & $3.2-5.0$ \\
O'Sullivan & Boston & 2.5 \\
Beischer & India & 15 \\
Ranchod & India & 3.8 \\
\hline
\end{tabular}

The age group for which GDM test was conducted ranged from 18 - 40 yrs. Majority of patients were in the age group of 21-25 yrs. in both the groups (Table 2). Advancing maternal age is associated with increased trend of gestational diabetes. The incidence of GDM was $66.66 \%$ in multigravida in both the groups (Table 3). Socioeconomic status was inversely associated with risk of GDM. The risk of GDM was two-thirds higher in women with lowest socioeconomic status. According to Timothy D. Dye et al,(7) women of higher socioeconomic status who were obese and did not exercise had high risk of GDM compared to their counterparts of lower socioeconomic status. In this study, the incidence of GDM was high in women belonging to class $\mathrm{V}$ socioeconomic status (88.88 \% in O’Sullivan group and $83.33 \%$ in DIPSI group-
Table 4). Majority of diabetic patients had BMI of $>25 \mathrm{~kg} / \mathrm{m}^{2}$ (73.33\% in 0'Sullivan group and $83.3 \%$ in DIPSI group-Table 5). There is strong association between high BMI and GDM which is similar to earlier study by Seshiah et al and Shin Y.Kim et al.(8) The proportion of GDM cases that belong to overweight, obesity and extreme obesity was $15.4 \%, 9.7 \%$ and $21.1 \%$ summing up to $46.2 \%$. Lifestyle intervention to reduce BMI can lower GDM risk. GDM was present in 55.55\% of patients with positive family history in O'Sullivan group and $49.99 \%$ in DIPSI group. Mother was diabetic in $22.22 \%$ and $16.66 \%$ of diabetic patients in O'Sullivan and DIPSI group respectively. Father was diabetic in $33.33 \%$ of diabetic patients in both the groups. (Table - 6). There was past history of Spontaneous Abortion and Pre-eclampsia in both groups (Table -7). In present pregnancy, the risk factors like pre-eclampsia was $2 \%$ in O'Sullivan group and $4.7 \%$ in DIPSI group and hydramnios was $6 \%$ in both the groups-(Table- 8 ). In this study, nearly all patients with GDM delivered at term. (Table -10). Rate of preterm delivery is same in both the groups. A study by Yariv Yogev et al (9) concluded that there was no difference in rate of spontaneous preterm delivery in GDM patients when compared to non-GDM patients. Out of 45 patients in O'Sullivan group, 38.88\% delivered by labour naturale with episiotomy, $27.77 \%$ by emergency caesarean and $33.33 \%$ by elective caesarean. In DIPSI group, $24 \%$ delivered by labour naturale, $31 \%$ by emergency caesarean and $43 \%$ by elective caesarean (Table -11). The most common indication for caesarean was foetal distress and previous LSCS. According to study by Hawthorne G Robson et al(10) the caesarean rate in diabetic patients is $75 \%$. In Gabbe et al(11) study, Caesarean section ranged from 50-80\% among GDM patients. Majority of babies of diabetic mother weighed between $2.5-4 \mathrm{~kg}(77.77 \%$ in O'Sullivan group and $68 \%$ in DIPSI group- Table -12). The incidence of macrosomia was $4 \%$ and $6 \%$ in O'Sullivan and DIPSI group respectively. Foetal macrosomia complicates $50 \%$ of women with GDM Gabbe.(12) According to study by R G Moses et al,(13) the mean birth weight of Infant of Diabetic Mother was 3293+/- $493 \mathrm{~g}$ when compared to matched groups, which had a birth weight of $3315+/-460 \mathrm{~g}$. Out of 45 patients diagnosed to be GDM in O'Sullivan group, 8 was on meal plan and 37 were started on 
insulin. Out of 63 GDM patients in DIPSI group, 16 were on meal plan and 47 were on insulin (Table -13). In women with well-controlled diabetes, the risk of respiratory distress was no higher when compared to general population. According to study by Kjos and Walther,(14) the incidence of respiratory distress syndrome was $0.95 \%$. In this study, there was no respiratory symptom. The reason for neonatal admission was low birth weight, preterm, sepsis, transient tachypnoea of newborn, hypoglycaemia and hyperbilirubinaemia. (Table 14). Hyperbilirubinaemia was reported in about $38 \%$ of pregnancies complicated by GDM. The incidence of hyperbilirubinaemia is $12.5 \%$ and the incidence of hypoglycaemia is $12.5 \%$ in both the groups. Only 35 patients in 0' Sullivan group and 57 patients in DIPSI group came for followup. In both the groups, GDM patients had normal plasma glucose levels on followup at 6 weeks using 75-gram OGTT. Only two women in DIPSI group continued to have increased glucose levels even after 6 weeks and were managed appropriately.

\section{CONCLUSION}

Screening with 50-gram 0'Sullivan's method has only 95\% specificity compared to screening with 75-gram DIPSI. DIPSI being a one-step procedure works both as a screening and diagnostic test for GDM. It avoids the need of multiple hospital visits, and multiple blood samples. This one step procedure of challenging pregnant woman with 75 -gram oral glucose appears to be simple, feasible and easily reproducible screening method of GDM.

\section{REFERENCES}

[1] Metzger BE, Coustan DR. Summary and recommendations of the fourth international workshopconference on gestational diabetes mellitus. The organizing committee. Diabetes Care 1998;21(Suppl2):B161-7.

[2] Dornhorst A, Rossi M. Risk and prevention of type 2 diabetes in women with gestational diabetes. Diabetes Care 1998;21(2):B43-9.

[3] Wilkins-Haug L, Horton JA, Cruess DF, et al. Antepartum screening in office-based practice: findings from the collaborative ambulatory research network. Obstet gynaecol 1996;88(4 Pt 1):483-9.
[4] Seshiah V, Balaji V, Balaji MS, et al. Prevalence of gestational diabetes mellitus in south India (Tamil Nadu) - a community based study. J Assoc Physicians India 2008;56:329-30.

[5] Seshiah V, Balaji V, Balaji MS, et al. Gestational diabetes mellitus in India. J Assoc Physicians India 2004;52:70711.

[6] Prathibha SD, Rashmi K, Anitha N, et al. Comparative study of efficacy of DIPSI and O'Sullivan's method of screening for GDM. Journal of Evidence based Medicine and Healthcare 2015;2(9):1289-94.

[7] Dye TD, Knox KL, Artal R, et al. Physical activity, obesity and diabetes in pregnancy. American Journal of Epidemiology 1997;146(11):961-5.

[8] Chu SY, Abe K, Hall LR, et al. Gestational diabetes mellitus: all Asians are not alike. Preventive Medicine 2009;49(2-3):265-8.

[9] Yogev Y, Langer 0. Spontaneous preterm delivery and gestational diabetes: the impact of glycemic control. J Archives of Gynaecology and Obstetrics 2007;276(4):361-5.

[10] Hawthorne G. Maternal complications in diabetic pregnancy. Best Practical Res Clin Obstet Gynaecol 2011;25(1):77-90.

[11] Gabbe SG, Graves CR. Management of diabetes mellitus complicating pregnancy. Obstet Gynecol 2003;102(4):857-68.

[12] Gabbe S, Gregory RP, Power ML, et al. Management of diabetes mellitus by obstetricians-gynecologists. Obstet Gynecol 2004;103(6):1229-34.

[13] Moses RG, Moses M, Russell KG, et al. The 75-g glucose tolerance test in pregnancy: a reference range determined on a low risk population and related to selected pregnancy outcome. Diabetes care 1998;21(11):1807-11.

[14] Kjos SL, Henry OA, Montoro M, et al. Insulin-requiring diabetes in pregnancy: a randomized trial of active induction of labor and expectant management. Am J Obstet Gynecol 1993;169(3):611-5. 